\title{
Effects of Supplemental Chinese Traditional Herbal Medicine Complex on the Carcass Quality of Pigs
}

\author{
Hui-Shuang Yeh, Kou-Joong Lin, Chun-Kuang Chou \\ Department of Animal Science \\ National Chiayi University, Chiayi, Taiwan, R.O.C. \\ Tu-Fa Lien(Corresponding author) \\ Department of Animal Science, National Chiayi University, \\ 300 University Road, Luh Liau Li, Chiayi, Taiwan, R. O. C. Fax: 88652750134 \\ Tel: 886-5271-7536 E-mail: tflien@mail.ncyu.edu.tw
}

Chia-Mo Liao

Bioking Technology Co., Ltd, Taiwan, R.O.C.

Received: April 2, 2013 Accepted: April 19, 2013

doi:10.5296/jas.v1i2.4317ＵRL: http://dx.doi.org/10.5296/jas.v1i2.4317

\begin{abstract}
This study was to investigate the effect of adding Chinese traditional herbal medicine complex in diets on the carcass quality of the pigs. 100 crossbred growing pigs (LYD) $(44.5 \pm$ $1.63 \mathrm{~kg}$ ) were randomly divided into 5 groups including supplementation $0.0,0.3,0.5$ and $0.7 \%$ Chinese herbal medicine complex (CHM), and antibiotics groups (chlortetracycline 100 ppm and oxytetracycline $100 \mathrm{ppm}$ ) with four replicates. Experimental results indicated that meat polyphenol and flavonoids content in the group with $0.7 \% \mathrm{CHM}$ addition, and the Hunter a value in the $0.5 \%$ and $0.7 \%$ CHM groups was better than those of the control and antibiotics groups $(\mathrm{P}<0.05)$. The panel evaluation revealed that the $0.7 \%$ CHM supplemented group had better values for juiciness and overall-acceptance than the control and antibiotics groups $(\mathrm{P}<0.05)$. In conclusion, supplementation of Chinese herbal medicine complex in pig's diet had beneficial effects on meat quality, and $0.7 \% \mathrm{CHM}$ addition had the best results for meat
\end{abstract}


quality.

Keywords: Chinese traditional herbal medicine, Carcass quality, Pigs

\section{Introduction}

Oxidative processes in meat are the most important factors that are responsible for quality deterioration including losses in flavour, colour and nutritional value (Fellenberg and Speisky, 2006; Kanner, 1994; Nissen et al., 2004). Products of lipid oxidation damage cell structure and functions, and may produce toxic metabolites of peroxides (Esterbauer, 1993) which have been implicated in deterioration of physiological functions (Fellenberg, and Speisky 2006; Miller and Brzezinska-Slebodzinska, 1993). It has also been found that lipid oxidation products can cause pathological changes, inhibit activity of enzymes and increase the content of cholesterol and peroxides in blood, thus activating the process of atherosclerosis. Numerous researchers have also found that they have carcinogenic effects (Frankel, 1991). Thus, prevention of lipid oxidation during feeding, processing and storing of meat is essential for the maintenance of quality and safety (Rey et al., 2005).

A number of measures have been taken in order to prevent oxidative rancidity and off-flavours in processed meats (Nissen et al., 2004). Adding antioxidants to the feed can protect fat from oxidative deterioration and improve the antioxidant status of animal tissue, thus preventing or reducing oxidation both in vivo and post-mortem. The role of vitamin $\mathrm{E}$ and selenium in retarding lipid oxidation and improving colour stability is well recognized (Morrissey et al., 1998; Zhan et al., 2007). In industrial processing, mainly synthetic antioxidants are used. However, toxicologists and nutritionists have long noted the noxiousness of certain synthetic antioxidants. Moreover, chemical-free animal products are increasing popular nowadays. Thus, in the last few years, the interest in using natural antioxidants to prevent meat lipid oxidation and avoid the possible harmful effects of adding synthetic substances has increased.

The effects of other natural dietary compounds with antioxidant properties, such as flavonoids and polyphenols on the oxidative status of meat is less well known, but is being increasingly investigated with researchers exploring plant-based materials as sources of natural polyphenol or flavonoid antioxidants (Nissen et al., 2004), e.g. Green tea catechins (Mason et al., 2005). Plant extracts (Carpenter et al., 2007; Lee and Ahm, 2005; Gladine et al., 2007; Papageorgiou et al., 2003) have displayed decreased lipid oxidation. However, most research has looked at the natural antioxidant effect on stored meats. Few studies have investigated the effects of natural antioxidants on fresh meat quality.

Another important consumer driven demand pertinent to the meat industry has been the increased desire for healthy meat products. Some Chinese herbal medicine contains the polyphenols, flavonoids and polysaccharides (Haijto et al., 1989) reportedly have antioxidant abilities (Karpinska et al., 2001). In addition, our study has also shown that supplemental Chinese herbal medicine complex in pigs' diets had a positive effect on immunity, and appears to offer a potential substitute for antibiotics (Yeh et al., 2011). We hypothesize that supplementing animal diets with bio-substances exhibiting antioxidant property, may produce meat products that contain antioxidant substances and thus enhance meat quality. Thus, the 


\section{Al Macrothink}

Journal of Agricultural Studies

ISSN 2166-0379

2013, Vol. 1, No. 2

effect of Chinese herbal medicines on the carcass characteristics and meat quality was investigated in this study.

\section{Materials and Methods}

\subsection{Animal Treatment}

One hundred LYD crossbred growing pigs, averaging $44.5 \pm 1.63 \mathrm{~kg}$ were blocked according to weight, sex and litter origin, then randomly divided into 5 groups and four replicates each given different levels 0.0 (control group, basal diet, Table 1), 0.3, 0.5, and 0.7\% of CHM, and antibiotics groups (chlortetracycline $100 \mathrm{ppm}$ and oxytetracline $100 \mathrm{ppm}$, stop to supplementation at 1 month before marketing). CHM included: 25\% Salvia officinalis, 25\% Ocimum bacilicum, 25\% Lavandula angustifolia, 15\% Rosmarinus officinalis, 10\% Glycyrrhiza glabra (CHM was supplied by Bioking Tech. Co., Taichung, Taiwan). The CHM used the full plants extracted by boiling water, and this CHM underwent an acute toxic test with rats (1-40-fold of the recommended level) and was proved to be safe. Diets and water were supplied ad libitum until the end of the trial when the pigs reached about $120 \mathrm{~kg}$. At the final of experiment all pigs were sacrificed and the carcass characteristics were measured. Loin muscle samples were used for meat traits analysis.

The experimental animals were reared in accordance to the Guide for the Care and Use of Agricultural Animals in Agricultural Research and Teaching, and this study was approved by our institution's Animal Care and Use Committee.

Table 1. Composition of basal diet as feed basis

\begin{tabular}{|c|c|c|c|}
\hline Ingredient $\left(\mathrm{g} \mathrm{kg}^{-1}\right)$ & $40 \sim 50 \mathrm{~kg}$ & $50 \sim 80 \mathrm{~kg}$ & $80 \sim 120 \mathrm{~kg}$ \\
\hline Yellow corn meal & 662.3 & 690.2 & 727.2 \\
\hline Soybean meal & 218.8 & 166.5 & 127.9 \\
\hline Fish meal $(60 \%)$ & 40 & 20 & ----- \\
\hline Wheat bran & ---- & 50 & 85 \\
\hline Calcium phosphate, dibasic & 11.9 & 14.9 & 13.0 \\
\hline Limestone, pulverized & 2 & 2 & 2 \\
\hline Soybean oil & 50 & 41.4 & 29.7 \\
\hline Iodized salt & 5 & 5 & 5 \\
\hline Vitamin premix $^{a}$ & 5 & 5 & 5 \\
\hline Mineral premix ${ }^{b}$ & 5 & 5 & 5 \\
\hline $\begin{array}{l}\text { Lysine } \\
\text { Total }\end{array}$ & $\begin{array}{l}---- \\
1000\end{array}$ & $\begin{array}{l}--- \\
1000\end{array}$ & $\begin{array}{l}0.2 \\
1000\end{array}$ \\
\hline \multicolumn{4}{|l|}{ Calculated value: } \\
\hline ME $\quad\left(\mathrm{MJ} \mathrm{kg}^{-1}\right)$ & 13.39 & 13.18 & 12.97 \\
\hline Crude protein (\%) & 18 & 15.5 & 13.2 \\
\hline Lysine (\%) & 0.95 & 0.75 & 0.6 \\
\hline Met + Cys (\%) & 0.54 & 0.44 & 0.35 \\
\hline Calcium (\%) & 0.6 & 0.5 & 0.45 \\
\hline Total phosphorus (\%) & 0.5 & 0.45 & 0.4 \\
\hline
\end{tabular}

a. Vitamin premix supplied the following per kilogram of diet: vitamin A, 5000IU ; vitamin $\mathrm{D}_{3}, 500 \mathrm{IU}$; vitamin $\mathrm{E}$, $5 \mathrm{mg}$; vitamin $\mathrm{K}, 1.7 \mathrm{mg}$; vitamin $\mathrm{B}_{1}, 0.6 \mathrm{mg}$; vitamin $\mathrm{B}_{12}, 20 \mathrm{mg}$; niacin, $25 \mathrm{mg}$; pantothenic acid, $13.3 \mathrm{mg}$.

b. Mineral premix supplied the following per kilogram of diet: $\mathrm{Fe}\left(\mathrm{FeSO}_{4} .7 \mathrm{H}_{2} \mathrm{O}, 20.09 \% \mathrm{Fe}\right), 117 \mathrm{mg} ; \mathrm{Cu}$ 
$\left(\mathrm{CuSO}_{4} .5 \mathrm{H}_{2} \mathrm{O}, 25.45 \% \mathrm{Cu}\right), 17 \mathrm{mg} ; \mathrm{Mn}\left(\mathrm{MnSO}_{4} . \mathrm{H}_{2} \mathrm{O}, 32.49 \% \mathrm{Mn}\right), 3.3 \mathrm{mg} ; \mathrm{Zn}\left(\mathrm{ZnSO}_{4}, 80.35 \% \mathrm{Zn}\right), 75 \mathrm{mg} ; \mathrm{Se}$ $\left(\mathrm{NaSeO}_{3}, 45.56 \% \mathrm{Se}\right), 0.17 \mathrm{mg} ; \mathrm{Co}\left(\mathrm{CoSO}_{4} \cdot \mathrm{H}_{2} \mathrm{O}, 32 \% \mathrm{Co}\right), 0.7 \mathrm{mg}$.

\subsection{Analyzed Traits and Methods}

CHM and pork flavonoids content were determined following the method described by Jia et al. (1999). A $500 \mu \mathrm{L}$ sample was taken, mixed with $1.5 \mathrm{~mL}$ ethanol, $100 \mu \mathrm{L}$ aluminum nitrate nonahydrate $\left(\mathrm{Al}\left(\mathrm{NO}_{3}\right)_{3}\right), 100 \mu \mathrm{L}$ of $1 \mathrm{M}$ potassium acetate $\left(\mathrm{CH}_{3} \mathrm{COOK}\right)$ and $2.8 \mathrm{~mL}$ distilled water. Forty minutes was allotted for the reaction to take place, and then flavonoids content was measured by a spectrophotometer (Hitachi, U-2000, Tokyo, Japan) at $415 \mathrm{~nm}$.

$\mathrm{CHM}$ and pork polyphenol content was examined according to the modified Folin-Ciocalteu method described by Roura et al. (2006). A $100 \mu \mathrm{L}$ sample, $0.1 \mathrm{~N}$ Folin-Ciocalteu reagent $250 \mu \mathrm{L}, 7.5 \%$ sodium carbonate $\left(\mathrm{Na}_{2} \mathrm{CO}_{3}\right) 200 \mu \mathrm{L}$ and deionized water $2.5 \mathrm{~mL}$ were mixed, allowed to stand at room temperature for $30 \mathrm{mins}$, and then the polyphenol content measured by a spectrophotometer (Hitachi, U-2000, Tokyo, Japan) at $260 \mathrm{~nm}$. Gallic acid was used as the standard.

\subsection{Carcass Characteristics}

Backfat thickness (skinless) was measured at three points (shoulder, last costal and lumbar rib), and then the values were averaged. The area of longissimus muscle transaction at the $10^{\text {th }}$ rib was drawn using a tracing paper. The area was then calculated with graph paper. Different parts of the carcass including shoulder, loin-belly and ham were measured.

\subsection{Meat Quality Analysis}

Water content was examined using the method of AOAC (2000). Crude fat content of the pork was determined based on the method of Folch (1957). Sample (10 g) was added to 50 $\mathrm{mL}$ solvent (chloroform: methyl alcohol, 2: 1) and crude fat was extracted for $4 \mathrm{hrs}$. After filtering, $10 \mathrm{~mL} 0.9 \%$ sodium chloride solution was added and the mixture was shaken to separate the oil and water layers. The substratum was then collected and dried.

The $\mathrm{pH}_{1}$ and $\mathrm{pH}_{24}$ value of meat were measured by a $\mathrm{pH}$ meter at $1\left(\mathrm{pH}_{1}\right)$ and $24\left(\mathrm{pH}_{24}\right)$ hrs postmortem. Sample of meat $(10 \mathrm{~g})$ was added to $100 \mathrm{~mL}$ distilled water, homogenized at $12235 \mathrm{rpm}$ for 3 mins, then examined by a pH meter (SP-2200, Sontex, Taiwan) (Ockerman, 1974).

To investigate the colour difference, the method of Lyon et al. (1980) was used. A colour difference meter (Model TC-1, Tokyo Denshoku Co., LTD) was used to determine the values of Hunt L for lightness, a for redness and b for yellowness of the samples.

Water holding capacity (WHC) was determined using the method of Lesiak et al. (1997). A $10 \mathrm{~mL} 1 \%$ sodium chloride solution was added to $5 \mathrm{~g}$ samples, placed in a $70-75{ }^{\circ} \mathrm{C}$ water bath for 30 mins, cooled, and centrifuged at $12235 \times$ g (Himac SCR 20B, Hitach, Japan). The supernatant was then collected and weighed. Water holding capacity was then calculated. 


\section{Ml Macrothink}

Journal of Agricultural Studies

ISSN 2166-0379

2013, Vol. 1, No. 2

Samples of muscle samples were cooked at $80^{\circ} \mathrm{C}$ for $15 \mathrm{~min}$, and a piece of $1 \mathrm{~cm}$ was cut off. The panel evaluation of the meat was performed by adequate qualified 20 persons who judged such characteristics as flavour, tenderness, juiciness and overall-acceptance. Each item was ranked on 1 to 7 scale, in which 7 was the highest grade.

\subsection{Statistical Analysis}

Data variances between groups in trial I and trial II were analyzed using SAS software (version 9.1.3, SAS, 1998). The significant differences between treatments were then determined by Duncan's multiple range test (SAS, 1998) according to the following model: $\mathrm{Y}=\mu+\mathrm{T}_{\mathrm{i}}+\mathrm{P}_{\mathrm{j}}+\mathrm{e}_{\mathrm{ijk}}$.

$\mathrm{Y}$ is the dependent variable, $\mu$ represents the mean, $\mathrm{T}$ is the treatment effect, $\mathrm{p}$ is the pen (replicate, experiment unit) effect and e is the random residual error term.

\section{Results}

The polyphenol and flavonoids in traditional Chinese herbal medicine complex were examined, and were revealed to be rich in polyphenol $(89.78 \mathrm{mg} / \mathrm{g})$ and flavonoids $(23.10 \mathrm{mg} / \mathrm{g})$.

\subsection{Effect of Supplemental CHM on Carcass Characteristics of Pigs}

Table 2 shows the effect of various levels of CHM supplementation on carcass characteristics. There were no significant differences in backfat thickness, loin-eye area, dressing percentage, shoulder, loin-belly and ham parts percentages of the carcass between CHM supplementation groups and control group $(\mathrm{P}>0.05)$. The backfat thickness in antibiotics group was lower than in control group $(\mathrm{P}<0.05)$.

Table 2. Effect of various levels of supplemental CHM on carcass characteristics of growing-finishing pigs

\begin{tabular}{|l|l|l|l|l|l|l|}
\hline & \multirow{3}{*}{ Control } & \multicolumn{3}{|c|}{ CHM } & & SEM \\
\cline { 3 - 7 } Items & $0.3 \%$ & $0.5 \%$ & $0.7 \%$ & Antibiotics & \\
\hline Live weight at slaughter $(\mathrm{kg})$ & 121.72 & 120.67 & 113.89 & 117.05 & 116.17 & 2.62 \\
\hline Carcass weight (kg) & 87.15 & 86.46 & 82.12 & 84.53 & 82.51 & 2.18 \\
\hline $\begin{array}{l}\text { Dressing percentage } \\
\text { (skinless) (\%) }\end{array}$ & 71.54 & 71.64 & 72.06 & 72.20 & 70.95 & 0.60 \\
\hline $\begin{array}{l}\text { Average backfat thickness } \\
(\mathrm{cm})\end{array}$ & $2.40^{\mathrm{a}}$ & $2.09^{\mathrm{ab}}$ & $2.21^{\mathrm{ab}}$ & $2.33^{\mathrm{a}}$ & $1.99^{\mathrm{b}}$ & 0.11 \\
\hline Loin-eye area $\left(\mathrm{cm}^{2}\right)$ & 47.80 & 50.72 & 45.84 & 47.67 & 48.89 & 1.64 \\
\hline Shoulder part $(\%)$ & 35.80 & 35.07 & 34.28 & 34.60 & 34.75 & 0.78 \\
\hline Loin-belly part $(\%)$ & 31.10 & 30.29 & 29.77 & 30.17 & 30.42 & 0.69 \\
\hline Ham part $(\%)$ & 33.10 & 34.64 & 35.95 & 35.23 & 34.83 & 1.39 \\
\hline
\end{tabular}

a.b , Means in the same row with no common superscript differ significantly $(\mathrm{P}<0.05) . \mathrm{n}=5 \mathrm{x} 4$

\subsection{Effect of Supplemental CHM on Meat Quality of Meat}

Shown in Table 3 is the effect of CHM at various levels of supplementation on the meat quality of the pork of trial II. The water holding capacity of the $0.5 \% \mathrm{CHM}$ group was better 
than that of the control and antibiotics groups $(\mathrm{P}<0.05)$. The moisture percentage of the $0.3 \%$ CHM group was higher than both of the 0.5 and $0.7 \%$ CHM groups $(\mathrm{P}<0.05)$. The control and $0.5 \%$ CHM groups had high level of crude fat compared with other groups $(\mathrm{P}<0.05)$. The Hunter a value from various levels of CHM supplementation was higher than control and antibiotics groups, especially the 0.5 and $0.7 \%$ CHM groups ( $\mathrm{P}<0.05)$. The $0.7 \%$ CHM group had higher Hunter $\mathrm{b}$ value than the antibiotics group $(\mathrm{P}<0.05)$. $\mathrm{The}^{\mathrm{pH}} \mathrm{H}_{1}$ value of the $0.5 \%$ $\mathrm{CHM}$ group showed the highest value among all the groups $(\mathrm{P}<0.05) \cdot \mathrm{pH}_{24}$ of the 0.5 and $0.7 \%$ CHM groups displayed higher values than of the control group $(\mathrm{P}<0.05)$. There was no significant difference in Hunter $\mathrm{L}$ value among the groups $(\mathrm{P}<0.05)$. The results revealed that the pork polyphenol and flavonoids contents of the CHM supplemented groups were higher than control and antibiotics groups $(\mathrm{P}<0.05)$. The levels of polyphenols and flavonoids in the CHM groups increased with the level of supplementation, with values being higher than both the control and antibiotics groups $(\mathrm{P}<0.05)$.

Table 3. Effect of various levels of supplemental CHM on meat quality of pork

\begin{tabular}{|c|c|c|c|c|c|c|}
\hline \multirow[b]{2}{*}{ Items } & \multirow[b]{2}{*}{ Control } & \multicolumn{3}{|c|}{ CHM } & \multirow[t]{2}{*}{ Antibiotics } & \multirow[t]{2}{*}{ SEM } \\
\hline & & $0.3 \%$ & $0.5 \%$ & $0.7 \%$ & & \\
\hline Water holding capacity (\%) & $69.65^{\mathrm{d}}$ & $72.82^{\mathrm{bc}}$ & $74.30^{\mathrm{ab}}$ & $75.17^{\mathrm{a}}$ & $72.59^{\mathrm{bc}}$ & 0.73 \\
\hline Moisture (\%) & 72.92 & 72.32 & 72.52 & 72.11 & 72.94 & 0.26 \\
\hline Crude fat $(\%)$ & $2.19^{\mathrm{a}}$ & $1.71^{\mathrm{bc}}$ & $2.07^{\mathrm{ab}}$ & $1.66^{\mathrm{c}}$ & $1.36^{\mathrm{c}}$ & 0.14 \\
\hline L value & 43.84 & 42.32 & 42.17 & 42.90 & 42.62 & 0.97 \\
\hline a value & $9.02^{b}$ & $9.24^{\mathrm{ab}}$ & $10.11^{\mathrm{a}}$ & $10.11^{\mathrm{a}}$ & $8.96^{\mathrm{b}}$ & 0.32 \\
\hline b value & $8.83^{\mathrm{a}}$ & $8.32^{\mathrm{ab}}$ & $8.58^{\mathrm{ab}}$ & $8.77^{\mathrm{a}}$ & $8.05^{\mathrm{b}}$ & 0.22 \\
\hline $\mathrm{pH}_{1}$ & $6.01^{\mathrm{bc}}$ & $5.92^{\mathrm{c}}$ & $6.27^{\mathrm{a}}$ & $6.25^{\mathrm{a}}$ & $6.16^{\mathrm{ab}}$ & 0.06 \\
\hline $\mathrm{pH}_{24}$ & $5.94^{\mathrm{b}}$ & $5.79^{\mathrm{b}}$ & $6.20^{\mathrm{a}}$ & $5.90^{\mathrm{b}}$ & $5.78^{\mathrm{b}}$ & 0.06 \\
\hline Polyphenol (mg g $\left.{ }^{-1}\right)$ & $34.57^{\mathrm{a}}$ & $38.74^{\mathrm{c}}$ & $40.16^{\circ}$ & $47.15^{\mathrm{a}}$ & $34.56^{\mathrm{a}}$ & 0.36 \\
\hline Flavonoids $\left(\mathrm{mg} \mathrm{g}^{-1}\right)$ & $2.67^{\mathrm{cd}}$ & $3.16^{\mathrm{c}}$ & $4.10^{\circ}$ & $5.86^{\mathrm{a}}$ & $2.34^{\mathrm{d}}$ & 0.20 \\
\hline
\end{tabular}

a,b Means in the same row with no common superscript differ significantly $(\mathrm{P}<0.05)$. $\mathrm{n}=5 \mathrm{x} 4$.

\subsection{Supplemental CHM on Panel Evaluation of Meat}

Listed in Table 4 are the results of the panel test for the various levels of CHM supplementation of trial II. Results showed that meat from the $0.7 \% \mathrm{CHM}$ supplemented pig diet was juicier and had better overall-acceptance than that of the control and antibiotics groups $(\mathrm{P}<0.05)$. There were no significant differences in tenderness, colour and flavour among the groups $(\mathrm{P}<0.05)$.

Table 4. Effect of various levels of supplemental CHM on panel evaluation of meat

\begin{tabular}{|l|l|l|l|l|l|l|}
\hline \multirow{2}{*}{ Items } & \multirow{3}{*}{ Control } & \multicolumn{3}{|c|}{ CHM } & & SEM \\
\cline { 3 - 6 } & $0.3 \%$ & $0.5 \%$ & $0.7 \%$ & Antibiotics & \\
\hline Tenderness & 4.56 & 4.64 & 4.73 & 4.79 & 4.64 & 0.17 \\
\hline Flavor & 4.56 & 4.44 & 4.68 & 4.79 & 4.63 & 0.16 \\
\hline Juiciness & $4.26^{\mathrm{b}}$ & $4.36^{\mathrm{ab}}$ & $4.30^{\mathrm{b}}$ & $4.82^{\mathrm{a}}$ & $3.88^{\mathrm{b}}$ & 0.17 \\
\hline Overall-acceptance & $4.56^{\mathrm{bc}}$ & $4.89^{\mathrm{abc}}$ & $4.96^{\mathrm{ab}}$ & $5.04^{\mathrm{a}}$ & $4.54^{\mathrm{c}}$ & 0.14 \\
\hline
\end{tabular}

\footnotetext{
${ }^{\mathrm{a}, \mathrm{b}}$ Means in the same row with no common superscript differ significantly $(\mathrm{P}<0.05) . \mathrm{n}=5 \times 4$.
} 


\section{Discussion}

\subsection{Effect of Supplemental CHM on Carcass Quality of Pigs}

The high colour difference of the Hunter a value implies that the Chinese herbal medicine group carcass has a good red colour. The high Hunter b value implies that the pork had high yellowness colour as well. This may result from the fact that the meat in the CHM groups contains antioxidants polyphenols and flavonoids. Zhan et al. (2007) found that meat colour of Hunter a value was increased in diets supplemented with selenium. Carpenter et al. (2007) indicated that grape seed and bearberry extracts marginally increased raw and cooked pork a redness value. Lee and Ahn (2005) also reported that plum extract increased Hunter a (redness) and $\mathrm{b}$ (yellowness) values of turkey breast.

Lin (2001) pointed out that the water holding capacity of the lean muscle was related to $\mathrm{pH}$ value because protein has an electric charge which enables it to hold water. When the $\mathrm{pH}$ value is lower or higher than the iso-electric point the water holding capacity is increased. In this study, the meat from the CHM group had better water holding capacity which may be related to the higher $\mathrm{pH}_{24}$ of the $\mathrm{CHM}$ group compared to the control and antibiotics groups.

Body fats were deposited in the order of intra-organ-kidney, stomach and intestines, inter-muscle, and intra-muscle and connective tissue. Deposition of fats in meat is related to the flavor, tenderness and juiciness of the meat, especially in muscle marbling (Lin, 2001).

There is not many data available concerning the effect of plant polyphenol and flavonoids extracts on the quality of pork. Meat colour and lipid stability are the major factors that limit the quality and acceptability of meat and meat products to consumers (Yang et al., 2002). Prevention of lipid oxidation during feeding, processing and storage of meat is essential for the maintenance of quality and safety (Fellenberg and Speisky, 2006; Rey et al., 2005). Researchers have developed measures to prevent oxidative rancidity and off-flavours in fresh and processed meats, such as the use of nitrites and synthetic antioxidants (BHA, BHT; Nissen et al., 2004). In the last few years, the interest in using natural antioxidants to prevent meat lipid oxidation is increasing, in order to avoid the possible harmful effects of adding synthetic substances. In this study the meat from the CHM group had a higher Hunter a value than the control, which may be the result of the antioxidants in the CHM supplementation, which contain the polyphenol and flavonoids have the antioxidant activities. Carpenter et al. (2007) reported that grape seed and bearberry extracts decreased lipid oxidation in raw pork on 9-12 days of storage.

\subsection{Effect of Supplemental CHM on Panel Evaluation of Meat}

Some sensory evaluation experts thought that the pork of the CHM groups had less odors than that of the control and antibiotics groups. Oxidative process in meat is the most important factors responsible for quality deterioration including flavour, colour and nutrition value (Kanner, 1994; Nissen et al., 2004). The antioxidant properties of polyphenols and flavonoids can inhibit the lipid oxidation. Lipid oxidation results in the free radical production which may lead to the oxidation of meat pigments and generation of rancid flavour. Nissen et al. (2004) and Lee and Ahn (2005) found that a plant extracted retarded 
lipid oxidation during irradiation or processing of meat, and lipid oxidation was involved in a decrease in positive perception of meat flavour/odor and a concomitant increase in the off-flavour/odors of fat rancid. Thus, the herbal extract displayed potential for maintaining the sensory eating quality of pork.

\subsection{Compared with Antibiotics}

The Chinese herbal medicine complex is natural origin and may be more acceptable to consumers. In addition, pork polyphenol and flavonoids content, Hunter a value, Hunter b value, $\mathrm{pH}_{1}$, juiciness and total acceptance of $\mathrm{CHM}$ group were better than those of the antibiotics group. Thus, CHM supplements may also improve the pork quality and be competitive with ordinary pork production.

\section{Conclusions}

This study indicated that supplementation of Chinese herbal medicine complex in the diet of pigs had beneficial effects on meat quality. The polyphenol and flavonoids in traditional Chinese herbal medicine complex may be integral to the Chinese herbal medicine complex function, that supplementation at the $0.3 \%$ level can trigger the effect, and $0.7 \%$ additive of $\mathrm{CHM}$ gives the best results for meat quality.

\section{References}

AOAC. (2000). Official methods of analysis. (14th ed). Washington, DC, USA: Association of Official Analytical Chemists.

Carpenter, R., O’Grady, M. N., O’Callaghan, Y. C., O’Brien, N. M., \& Kerry, J. P. (2007). Evaluation of the antioxidant potential of grapeseed and bearberry extracts in raw and cooked pork. Meat Sci. 76, 604-610. http://dx.doi.org/10.1016\%2Fj.meatsci.2007.01.021

Esterbauer, H. (1993). Cytotoxicity and gentoxicity of lipid-oxidation products. Am. J. Clin. Nutr. 57, 779-785.

Fellenberg, M. A., \& Speisky, H. (2006). Antioxidants: their effects on broiler oxidative stress and its meat oxidative. World's Poult. Sci. J. 62, 53-70. http://dx.doi.org/10.1079\%2FWPS200584

Frankel, E. N. (1991). Recent advances in lipid oxidation. A review. J. Sci. Food Agric. 54, 495-511. http://dx.doi.org/10.1002\%2Fjsfa.2740540402

Folch, J., Less, M., \& Stanley, G. H. S. (1957). A simple method for the isolation and purification of total lipid from animal tissues. J. Biolog. Chem. 226, 499-509.

Gladine, C., Morand, C., Rock, E., Bauchart, D., \& Durand, D. (2007). Plant extracts rich in polyphenols (PERP). are efficient antioxidats to prevent lipoperoxidation in plasma lipids from animals fed n-3PUFA supplemented diets. Anim. Feed Sci. Tech. 136, 281-296. http://dx.doi.org/10.1016\%2Fj.anifeedsci.2006.09.003

Haijto, T., Hostanska, K., \& Gabius, H. J. (1989). Modulatory potency of the $\mathrm{B}$-galactoside-specific lectin from mistletone extract (Iscador). on the host defense system in 
vivo in rabbits and patent. Cancer Res. 49, 483-4808.

Jia, Z., Tang, M., \& Wu, J. (1999). The determination of flavonoids content in mulberry and their scavenging effects on superoxide radicals. Food Chem. 64, 555-559. http://dx.doi.org/10.1016\%2FS0308-8146\%2898\%2900102-2

Kanner, J. (1994). Oxidative processes in meat and meat products:Quality implications. Meat Sci. 36, 169-189. http://dx.doi.org/10.1016\%2F0309-1740\%2894\%2990040-X

Karpinska, M., Borowski, J., \& Danowska-Oziewicz, M. (2001). The use of natural antioxidants in ready-to-serve food. Food Chem. 72, 5-9. http://dx.doi.org/10.1016\%2FS0308-8146\%2800\%2900171-0

Lee, E. J., \& Ahn, D. U. (2005). Quality characteristics of irradiated turkey breast rolls formulated with plum extract. Meat Sci. 71, 300-305. http://dx.doi.org/10.1016\%2Fj.meatsci.2005.03.017

Lesiak, M. T., Olson, D. G.., Lesiak, C. A., \& Ahn, D. U. (1997). Effects of post-mortem time before chilling and chilling temperatures on water-holding capacity and texture of turkey breast muscle. Poult. Sci. 76, 552-556.

Lin, K. J. (2001). Theory and technic of meat process. Hua Siang Yuan publish. Taiwan. pp.43.

Lyon, L. E., Lyon, B. G., Davis, C. E., \& Townsend, W. E. (1980). Tecture profile analysis of patties made from mixed and flake-cut mechanically debone poultry. Poult. Sci. 48, 393-943.

Mason, L. M., Hogan, S. A., Lynch, A., O’Sullivan, K., Lawlor, P. G., \& Kerry, J. P. (2005). Effects of restricted feeding and antioxidant supplementation on pig performance and quality characteristics of longissimus dorsi muscle from Landrace and Duroc pig. Meat Sci. 70, 307-317. http://dx.doi.org/10.1016\%2Fj.meatsci.2005.01.017

Miller, J. K., \& Brzezinska-Slebodzinska, E. (1993). Oxidative stress, antioxidants and animal $\begin{array}{lllll}\text { function. } J . & \text { Dairy } & \text { Sci. } & 76, & 2812-2823 .\end{array}$ http://dx.doi.org/10.3168\%2Fjds.S0022-0302\%2893\%2977620-1

Morrissey, P. A., Sheehy, P. J. A., Galvin, K., Kerry, J. P., \& Buckley, D. J. (1998). Lipid stability in meat and meat products. Meat Sci. 49, 73-86. http://dx.doi.org/10.1016\%2FS0309-1740\%2898\%2990039-0

Nissen, L. R., Byrne, D. V., Bertelsen, G., \& Skibsted, L. H. (2004). The antioxidative activity of plant in cooked pork patties as evaluated by descriptive sensory profiling and chemical analysis. Meat Sci. 68, 485-495. http://dx.doi.org/10.1016\%2Fj.meatsci.2004.05.004

Ockerman, H. W. (1974). Quality control of post-mortem muscle tissue. The Ohio State University and Ohio Agriculture Research. USA. pp. 91.

Papageorgiou, G., Botsoglou, A., Govaris, A., Giannenas, I., Iliadis, S., \& Botsoglou, E. (2003). Effects of dietary oregano oil and $\alpha$-tocopheryl acetate supplementation on iron-induced lipid oxidation of turkey breast, thigh, liver and heart tissue. J. Anim. Physiol. :A, Anim. Nutr. 87, 
324-335. http://dx.doi.org/10.1046\%2Fj.1439-0396.2003.00441.x

Rey, A. I., Hopia, A., Kivikari, R., \& Kahkonen, M. (2005). Use of naturnal food/plant extracts: cloudberry (Rubus Chamaemorus)., beetroot (Beta Vylgaris"Vulgaris"). or willow herb (Epilobium angustifolium). to reduce lipid oxidation of cooked pork patties. LWT 38, 363-370. http://dx.doi.org/10.1016\%2Fj.lwt.2004.06.010

Roura, E., Andrés-Lacueva, C., Estruch, R., \& Lamuela-Raventós, R. M. (2006).. Total polyphenol intake estimated by a modified Folin-Ciocalteu assay of urine. Clin. Chem. 52, 749-752. http://dx.doi.org/10.1373\%2Fclinchem.2005.063628

Statistical Analysis System Institute Inc. (1998). SAS/STAT User's guide: statistics, Version 6.06, Cary, NC, USA: SAS Institute Inc.

Yang, A. M., Brewster, J., Lanari, M. C., \& Tume, R. K. (2002). Effect of vitamin E supplementation on $\alpha$-tocopherol and $\beta$-carotene concentrations in tissues from pasture-and $\begin{array}{lllll}\text { grain-fed } & \text { cattle. } & \text { Meat } & \text { Sci. } & 60,\end{array}$ http://dx.doi.org/10.1016\%2FS0309-1740\%2801\%2900102-4.

Yeh, H. S., Weng, B. C., \& Lien, T. F. (2011). Effects of Chinese traditional herbal medicine complex supplementation on the growth performance, immunity and serum traits of pigs. Anim. Sci. J. 82, 747-752. http://dx.doi.org/10.1111\%2Fj.1740-0929.2011.00897.x

Zhan, X. A., Wang, M., Zhao, R. Q., Li, W. F., \& Xu Z. R. (2007). Effects of different selenium source on selenium distribution, loin quality and antioxidant status in finishing pigs. Anim. Feed Sci. Tech. 132, 202-211. http://dx.doi.org/10.1016\%2Fj.anifeedsci.2006.03.020

\section{Copyright Disclaimer}

Copyright reserved by the author(s).

This article is an open-access article distributed under the terms and conditions of the Creative Commons Attribution license (http://creativecommons.org/licenses/by/3.0/). 